\title{
The effect of integrated course and faculty development: experiences of a university chemistry department in the Philippines ${ }^{1}$
}

\author{
Marilou R. Gallos, University of San Carlos, Cebu City, Philippines \\ mrgallos@staff.usc.edu.ph \\ Euwe (Ed) van den Berg, University of Utrecht, Utrecht, Netherlands \\ e.vandenberg@phys.uu.nl \\ David F. Treagust, Curtin University of Technology, Perth, Western Australia \\ d.f.treagust@curtin.edu.au
}

\footnotetext{
${ }^{1}$ The work described was part of the Science Teacher Education Project Southern Philippines (STEPS) executed jointly by the University of San Carlos, Cebu City, Philippines and the Vrije Universiteit, Amsterdam, Netherlands and financed by the Netherlands Government.
} 


\title{
The effect of integrated course and faculty development: experiences of a university chemistry department in the Philippines
}

\begin{abstract}
It is widely recognized that lectures continue to dominate college chemistry instruction, especially in developing countries, and that lectures limit student intellectual engagement. To address this concern, a General Chemistry course in a Philippine university was reconstructed to implement an instructional cycle consisting of three phases: a plenary or mini-lecture, seatwork activity, and a summary or closure. An expert instructor coached the instructors to improve their teaching. Two instructors were involved in pilot implementation and 13 instructors in a large-scale implementation. This article describes the instructors' adoption of the instructional cycle using qualitative and quantitative methods that involved multiple data sources. The instructional cycle and intensive coaching enabled most instructors to change their practices, shift their focus from teaching to learning, and enhance their knowledge of student learning difficulties. Nine instructors were able to significantly change their teaching and apply meaningful student seatwork in their lessons. These 9 instructors used student seatwork and activities $30 \%-70 \%$ of the time whereas previously $90 \%$ of the time involved lectures. Videotape records showed that more than $70 \%$ of the students were continuously on task. Four instructors had considerable difficulties in applying the new approach but also had difficulties with conventional lectures. The project constituted the start of a departmental reorientation with a focus on effectiveness of teaching and learning. Subsequently the faculty and course development model developed in this study was used to revise courses. The theory of Rogan and Grayson (2003) proved useful in describing the change processes.
\end{abstract}

\section{Introduction}

During the past two decades, dynamic and integrated teacher development initiatives have emphasised desirable teacher behaviours that explore students' initial understanding, encourage a high level of performance and assist students in learning how to learn (Beeby, 1980; Bell \& Gilbert, 1996; Loucks-Horsley et al., 1998; Robbins, 1991; Showers, 1985; 
Showers \& Joyce, 1996). One problem in adopting these teacher development initiatives is that teachers have rarely, if ever, experienced these methods themselves. Consequently, in order to sustain such an adoption, teacher development programs are needed that continuously inform the teacher and assist in adopting the necessary changes.

A variety of techniques have been recommended to enhance teachers' adopting more effective teaching methods. For example, the direct instruction model described by Rosenshine (1983) involved six steps or functions: (1) review, check work of the previous lesson and re-teach if necessary, (2) present new academic content or skills, (3) provide initial but guided student practice and check for understanding, (4) provide continual feedback and correctives, (5) provide students with opportunities for independent practice and, (6) conduct weekly and monthly reviews. The same steps were implemented by successful teachers in their conventional teaching as described in Walberg's (1991) meta-analysis of student achievement. Kohler et al. (1997) and Peterson (1979) have used this model in the teaching of reading and mathematics, respectively, at the elementary and junior secondary level.

Research has shown that immersion and workshop strategies for professional learning need to be supplemented by school and classroom support through coaching. (Joyce \& Showers, 1988; Showers \& Joyce, 1996; Wolfe \& Robbins, 1989), to improve teachers’ ability to plan and organize classroom activities (Koballa, 1992; Munro \& Elliot, 1989), to use effective teaching behaviours (Showers, 1985), and to enhance teachers' ability to employ classroom behaviour management strategies (Pugach \& Johnson, 1995; Vail et al., 1997). Without coaching, no long-term changes in teaching behaviours are likely to occur.

Recently Rogan and Grayson (2004) published a theory of curriculum implementation, which is clearly linked to professional development in developing countries. Their theory takes account of the institutional environment and the heterogeneity in terms of teacher background. The central constructs are Profile of Implementation, Support from Outside Agencies, and Capacity to Support Innovation and these constructs are linked to measurable indicators. Profile of Implementation is an attempt to understand and express the extent to which the ideals of a set of curriculum proposals are being put into practice. It does include the idea 
that there are as many implementations as teachers and that implementation might follow different developmental paths with nothing as practical as next steps (Fullan, 1991). The Capacity to Support Innovation is an attempt to understand and elaborate on the factors that are able to support or hinder the implementation of new ideas and practices. In each school setting this capacity may have a different profile of physical resources; teacher backgrounds, experience, training, and commitment; students; and management. Outside Agencies are organizations outside the school such as Departments of Education and donor agencies, which interact with the school to facilitate innovation. For each of these main concepts tables are provided in the original article to show the different variables involved and quantify different levels.

Rogan and Grayson formulated the following propositions:

1. There is a zone of feasible innovation. Innovation is most likely to take place when it proceeds just ahead of existing practice. Implementation of an innovation should occur in manageable steps.

2. Capacity to Support Innovation needs to be developed concurrently with efforts to enrich the Profile of Implementation.

3. The provision of Outside Support should be informed by the other two constructs. The capacity of the school (or Department) needs to be taken into account in determining the nature and extent of implementation. Support with the desired implementation then needs to go hand in hand with the development of capacity.

4. All role players, but especially those who are most directly involved, need the opportunity to reconceptualize the intended changes in their own terms and for their own context.

5. Changing teaching and learning practices should be viewed as a change of culture rather than merely a technical matter. 
6. Implementation will be most likely to succeed when there is alignment between the three constructs and the primary level of the system.

The Philippines has an unusually high participation rate in post secondary education with over 1400 colleges and universities offering vocational and degree courses for graduates of the four-year secondary school (Acedo, 2002). However, one longstanding problem is how to ensure that effective instructional practices find their way into teachers' routines (Golla \& Guzman, 1998). The absence of a science culture, flaws in teacher training, curriculum and instructional materials and the teaching-learning process, are major factors in the low achievement of Filipino students in science and mathematics (Ibe \& Ogena, 1998). The majority of science teachers, particularly in physics and chemistry, lack subject matter mastery as well as adequate pedagogical content knowledge for effective teaching (Balce, \& et al., 2000; Somerset et al., 1999).

According to recent common observations in Philippine secondary and post-secondary classrooms (Berg et al., 1998; Somerset et al., 1999; Gallos, 2003):

- Students are passive with instructors talking 90-100 \% of the lesson time;

- Alternatives to lectures such as board work, group work and reporting are often applied but most students are mentally passive while listening to superficial presentations of fellow-students;

- The teaching focus is on doing standard problems and not on concepts, conceptual difficulties, and the role of context in applying science concepts.

- There is often blind formula work without the conceptual understanding which is needed to realise whether results of computations are sensible;

- Concepts are introduced deductively through abstract definitions without building up an intuitive feel and understanding for the concept through examples and extensive linking with prior knowledge and everyday manifestations of the concept;

- Students have no books and mainly study from notes taken in class; however, low cost editions of international texts are available and sometimes can be rented cheaply;

- The taught and assessed curriculum are very different from the intended curriculum as described in the syllabus in terms of level and extent of coverage;

- College teachers in Physics and Chemistry may not be majors in these subjects; even if they are, that is not a guarantee for mastery of the subject matter taught; 
- There is no systematic and sustained effort of instructors to stimulate and maintain student work in the course (the instructor may give homework assignments but rarely checks or uses the assignment in class, thus undermining student dedication);

- Sometimes the classroom atmosphere, especially for engineering students, is so noisy that learning seems impossible. However, this problem is not officially recognized as a factor contributing to low performance. College instructors often feel that keeping discipline to create a good learning atmosphere is the responsibility of students rather than of the teacher. This perception is reinforced by a culture which avoids direct disciplining;

- Many students may enter quite late or have irregular attendance; some students enter the class even without notebooks or ballpoints.

This correctly described the situation we found in our General Chemistry classes.

This article describes and analyses how the authors applied principles of effective teaching to the process of course and faculty development in chemistry classrooms in a university in the Philippines (Biggs, 1999; Medley, 1979; Rosenshine \& Stevens, 1986; Walberg, 1991). Based on the authors' experience working in higher education in the Philippines and the research on effective teaching, this research investigated how the instructors modified their teaching behaviour as a result of an integrated course and faculty development process. This comprehensive approach included common sense rules for course and classroom management; a clear and detailed course manual with objectives, teaching-learning activities, and assessment; application of a three phase instructional cycle consisting of a plenary or mini-lecture, student activities or seatwork, and closure or summary; small group and departmental meetings of instructors; and coaching in the classroom. In the conclusion section we will look back at the faculty development process and evaluate it in terms of the theories of Rogan and Grayson (2003) and Fullan (1991, 2001).

\section{Methodology}

The implemented instructional cycle

The direct instruction model of Rosenshine (1983) was used as the basis for the three phases in the instructional cycle approach in the revised general chemistry course. The six steps were condensed into a three-stage instructional cycle shown in Figure 1 to assist the instructors in changing from lectures to lessons that included student work and teacher feedback on student work. 
The plenary lecture phase of the instructional cycle, which combined steps one and two of Rosenshine's model, included a short presentation of new information, or a mini-lecture, after the teacher initiated a brief review or check on the last session activities. The seatwork activity, the second phase, combined steps 3, 4 and 5 of Rosenshine's model and consisted of students working on problems, questions or activities with the instructor moving around the classroom. During the seatwork activity phase, the students discuss conceptual questions, answer textbook questions and problems, while the teacher goes around to first make sure that everybody works and then interacts with individuals or small groups about problems in the assignment. During the third phase of the cycle the teacher leads a plenary discussion on the main problems that surfaced during seatwork and provides closure and a summary. The instructional cycle can be implemented once, twice or more in an hour or 1.5 hour session, depending on lesson content.

Place Figure 1 about here

Considering the Philippine classroom situation described earlier and the literature on effective teaching (Fullan, 1993; Fullan \& Stiegelbauer, 1991; Hopkins, 2002), the course revision also incorporated the following components:

- Student discipline: The teacher has to enforce discipline in coming on time and being prepared (book, paper, pen) and behaving in class.

- Course organization: Objectives, readings, assignments, and assessment have to be made explicit and consistent with one another.

- Teaching/Learning: The instructional process was to be restructured in such a way to assist teachers with relatively weak backgrounds and a narrow teaching repertoire that includes mainly lecturing. A modified instructional process should be a first step to a wider teaching repertoire.

- Coaching: changes in teaching repertoire require in-classroom coaching by experts.

- Textbook: considering the background and experience of the instructors, a textbook should have a central place as a source for readings (replacing lectures in part) and assignments (to encourage students to work). At a much later stage in the development, instructors may want to make the course less textbook-bound.

- To scaffold the changes, it is necessary to organize small group meetings, individual consultations, and faculty meetings for support in addition to coaching. 
- Involvement of the head of Department and other senior faculty in the course reconstruction, coaching, and seminars/workshops.

The research setting and sample

The study was conducted in the Chemistry Department of a private university in the Philippines and involved 13 instructors who taught a first year General Chemistry course. Students in the Philippines enrol in six years of primary school followed by four years of high school; college or university starts after 10 years of schooling. The science curriculum in high school follows an American model. In college/university, the first two of four years are occupied with introductory or liberal arts courses; General Chemistry is one of the courses taken.

The instructors of General Chemistry ranged in experience from half a year (two instructors) to more than 20 years (four instructors) and all had qualifications in chemistry - nine instructors held Bachelor's degrees, three held Masters degrees and one a $\mathrm{PhD}$ (from Austria); nine of the instructors were female. We have identified the instructors by letters, A to M. The researcher and main coach involved in this study was the first author, a doctoral student in Chemistry Education with almost 20 years experience in teaching High School and College Chemistry. She has a dynamic personality and is a good organiser. The expatriate project supervisor and coach has over 20 years of experience in teaching physics and teacher education in several countries including four years of experience in the local setting at the time of the study. He knew all instructors personally, attended course sessions regularly as a coach, and attended departmental sessions. A former Chair of the Department of Chemistry contributed many of the teaching ideas and played an important role in advising on course development as well as on many interpersonal aspects. The Department Chair and DeputyChair were both Filipino Chemistry $\mathrm{PhD}$ holders from universities in Japan and Australia with ample teaching experience and a great interest and sensitivity for improving teaching and learning. They visited classrooms and acted as resource persons.

\section{Course organisation and redesign}

In close consultation with colleagues in the Department of Chemistry, the first author developed a new version of the General Chemistry course. In this first version, the locally popular international edition of Mortimer (1986) was used as the basis for most seatwork and reading assignments. A course manual identified learning targets/objectives for each lesson 
and specified activities and seatwork based on the book or worksheets from other sources. The course manual also suggested demonstrations and other teaching learning activities for each lesson. The new version of the first year General Chemistry course was implemented in two stages.

In the first stage, two instructors taught the first version of the course for one semester to 55 engineering student in each class. The first author attended every session and assisted the instructors by acting as a coach in developing the teaching skills required. The course material was substantially revised and implemented again in the summer (2000) session by one of the two instructors. Fourteen other instructors from the Department of Chemistry attended one of six weekly observing sessions, in small groups, to monitor the teaching method. These instructors also participated in a weekly training session and in a further revision of the course material that involved a new textbook by Brown, LeMay and Bursten (2000) that had problems for individual and group work, consistent with the instructional changes being implemented. These training sessions included the revision of all classroom seatwork/activities and homework and this provided an opportunity for other instructors to be involved in rethinking General Chemistry and gaining ownership of the newly developed course. These sessions provided an opportunity to reconceptualise (Rogan \& Grayson, 2003) the course and the teaching.

In the second stage (first semester 2000-2001), 13 instructors implemented the third version of the course in 14 parallel sections of first year engineering students (one instructor taught two sessions). In small groups with the first author, the instructors had weekly sessions on implementation problems and there was a monthly session with all instructors on chemistry content, presentation, and organization. The first author and two other colleagues -- one an expert in science pedagogy and the other an expert on chemistry content -- regularly observed lessons and provided feedback and assistance to the instructors and contributed to the monthly sessions.

At an institutional level, the Department Head and senior faculty were not only involved in their decision making/approval capacities, but were also directly involved in course revision. 
This research used a case study approach that focused on one phenomenon (the teaching and learning in the first year chemistry classrooms of one university), was descriptive (providing rich illustrations of that phenomenon) and was heuristic (providing sources for further investigation of the phenomenon) (Merriam, 1998). Both qualitative and quantitative methods of data collection were employed. The qualitative data included classroom observations, video-recording of teaching, records of instructor meetings, as well as interviews with students and instructors. To ensure a high level of reliability, these data were triangulated using different modes (classroom observations, interviews, journal records and videotapes of classes) and investigator triangulation included independent persons, member checks and peer reviews (Stake, 2000).

Analysis of these data enabled the researchers to establish the effectiveness of the instructional cycle in terms of instructors adopting or adapting the three phases in the instructional cycle, improving the basics of teaching that included use of the textbooks, limiting student tardiness, enhancing student attendance, improving classroom management and enhancing instructor knowledge of student learning difficulties.

The quantitative data included results on a student questionnaire with factual questions about the teaching, and time measurements and ratings derived from videotaped lessons by a team of three raters.

\section{Results and discussion}

Before implementation

Before the project started, video recordings were made in the classes of nine instructors. One recording had been pre-announced (best teaching) and the other recording had not been announced to the teacher (typical teaching). During the second stage of the implementation, after teachers had ample opportunity to adjust to the new ways of teaching, again two recordings were made, one announced and one unannounced. The video recordings were then analysed for time on task, time spent on the plenary lecture compared to seatwork, number of questions asked, level of questions and other variables to be encountered in the discussion section. Six of these nine instructors were involved in the main study. 
Each of the nine instructors provided negligible time for giving feedback on the student's work or making some form of a closure or summary of the lesson. This meant that students rarely had any opportunity to identify their own learning difficulties, to ask questions, and obtain feedback from the instructor. Furthermore, instructors asked many questions within a 35-minute plenary session, of which the majority were answered in chorus (for example, instructor E asked 52 questions of which students answered 36 in chorus and only eight were answered individually). Questions with choral answers usually are responses to memory questions.

In nine of the 18-videotaped lessons, the strategy used by the instructors was to write one to two algorithmic problems on the chalkboard and announce to the class that everybody should work on the calculations in their notebooks. Just after the announcement was given, the instructors called one or two students to work through calculations on the chalkboard even though other students had not yet started on their own calculations. Usually the most active and competent students were selected to do the board-work and so the students working on the board were likely to be more competent than the other students in the classroom. The result was that the other students did not try to solve the problem; they just copied from the chalkboard. Oftentimes the conversation in the classroom was between the students working on the board and the instructor, neglecting other students.

In eight of 18-videotaped classes, the instructors had given homework in the previous lesson; however, only one instructor had a quick visual check to see whether or not students had done their homework. In all the classes observed, the majority of the students came to class without textbooks. Indeed, the textbook was rarely used in class as the instructor simply gave lectures and wrote definitions, formula and other notes on the chalkboard.

Much time was wasted by late starts due to tardy students and teachers not demanding better attendance habits. In the unannounced video recordings, the actual time spent on the lessons, which was either one or 1.5 hours, ranged from a low of 33\% to a high of $79 \%$ of official lesson time with a mean (standard deviation) of 63\% (13\%). In the announced video results were better with a range from $49 \%$ to $93 \%$ and mean (standard deviation) of $70 \%$ (14\%) of lesson time used productively. In the unannounced video only one of nine instructors spent 
time on seatwork/activities while the others spent all effective lesson time in plenary lecture with low-level interaction. In the announced video, three instructors had some individual work but one of those involved a quiz.

The observations above are typical for Philippine college teaching: lectures may be interactive, but with questions that are low level and solicit chorus answers. The teacher is duped into thinking that the class is lively and involved (chorus answers) yet there is little intellectual discourse or mental activity of students.

\title{
During implementation
}

The instructional cycle was implemented in all chemistry classes as the normal teaching scheme. However, as in all educational projects involving teacher change, this one also created uncertainty among the participating instructors as illustrated by the following remark: In the past my teaching was spontaneous but now with this style of teaching, I'm lost in the middle and many times caught asking myself these questions: What will I do next? Where am I now? So I had to look at the course manual every now and then. Anyway, as time goes on I will learn and become familiar with the style. (Instructor I: 30/06/00)

\begin{abstract}
Almost all students in 11 of the 14 classes either borrowed books from the university textbook department or bought and used them during seatwork and homework. However, three instructors did not enforce the book policy and kept writing notes and assignments on the board. Tardiness of students was monitored and the number of students coming late was reduced. In three classes, tardiness problems remained due to instructors and the majority of the students being late most of the time and needing a long time to settle down. The instructors who utilized their time most effectively had made agreements with their students about an early start and enforced the agreements. In one case, the whole group had their previous class in an adjacent building and they would show up all at the same time making for an effective start. There was a better utilization of the class time as evidenced by the increased percentage of time spent for actual teaching which ranged from $50 \%$ to $96 \%$ with a mean (standard deviation) of 77\% (12\%). Yet individual differences between teachers were still considerable, partly due to classroom discipline problems.
\end{abstract}


Plenary lecture. All 13 instructors implemented the three phases of the learning cycle (see Table 1). Six instructors (B, F, G, H, I \& L) utilized less than $40 \%$ of the actual instructional time for plenary lecture. Three instructors (C, J, \& K) had a range of $40-50 \%$ of the instructional time spent for plenary while four instructors (A, D, E \& M) spent more than 50 $\%$ of the actual teaching time for plenary lecture. Instructor $E$ used the highest percent of actual time (78 \%) for the plenary lecture. Instructors A, D, E, and M were observed to have classes which were noisy and they did not do enough to control student misbehaviour.

Place table 1 about here

The instructors asked a combined total of 214 questions during the lecture phase, 83 of which were answered in chorus, 83 individually, and 15 by the instructor. Six of the 13 instructors had been included in the group observed before the project so their question behaviour could be compared (Table 2). Although the percentage of choral answers is still too high, the reduction of choral answers and the increase in the percentage of individual answers is striking.

Place table 2 about here

Seatwork activity. Of the 13 instructors, six (B, F, G, I, J, \& L) utilized a substantial range of time (40-60 \%) for seatwork activity, while five instructors (A, C, H, K \& M) allocated 20 $40 \%$ of the actual teaching time for seatwork. Only instructors D and E had relatively little class time used for student seatwork activity. The six instructors were found to have good control of the class and no behaviour problems were observed. Videotape records showed that more than $70 \%$ of the students were continuously on task with 9 of the 13 instructors (see table 3).

Place table 3 about here

The observations regarding the behaviour of teachers during the crucial seatwork phase presented in table 3 show how time was spent. At the beginning of the semester much of the seatwork/activities was conducted in groups of 4 or 5 students or even more. The reason was that many instructors felt they had to collect and grade results of seatwork in order to be taken serious by the students. Later the instructors realized that students would also work seriously 
if work was not graded provided that the instructor showed a serious interest in the work during class time and integrated the work clearly in the learning process. Grading seatwork is actually counterproductive as it shifts the focus from concepts to points (Black \& Wiliam, 1998) and undermines the intrinsic motivation of students.

All instructors gave seatwork and moved around the classroom looking at student work, and interacted with students. Not listed in this table is the fact that none of the teachers sat down and did his/her own work, a behaviour that was common prior to the research and elsewhere in the Philippines. In nine of the 13 classes, over $70 \%$ of the students were at work. On the other hand, no demonstrations were performed and none of the tasks required students to interpret given data, construct a graph, or make an inference. Further course and faculty development is needed to provide a wider range of teaching and learning activities.

Several undesirable practices were observed: Six instructors interacted with students as a whole class while the latter were on task. This is quite common when teachers start using seatwork, they keep giving instructions and use individual questions of students to provide plenary answers. That is counterproductive as students are then confused and switch back to their passive lecture mode. During one series of classroom observations, four instructors wrote notes on the board during seatwork activities. The notes contained instructions/hints for the problems. However, when the researcher checked the textbook, it was found that the hints were in the book. It would have been better for the instructor to refer to the book and use the writing time to interact individually with students during the seatwork. These are the kinds of teacher reactions that can be corrected with coaching.

Closure. The closure phase was intended for discussion of common student problems with the seatwork and reiteration of the main points of the lesson (summary). The time for closure varied considerably among instructors. Usually instructors reacted to the seatwork they had observed and wrote solutions to selected seatwork problems on the board. Quite often the closure phase became another lecture although now partially based on real student problems during the seatwork phase rather than just disconnected from student difficulties with the subject matter (as before). Eleven instructors answered questions during this phase but such answers easily became little lectures. Only five instructors gave a summary. Almost all instructors asked questions during this phase, ranging from $2-20$ questions in a $5-10$ minute closure. As in the plenary, instructors still remained too tolerant of choral answers. 
Comments on the changes in instructional format

The emphasis on greater discipline in the classroom and the implementation of the instructional cycle required improvement of classroom management skills plus learning of some new skills such as creating and maintaining an atmosphere for productive seatwork. Over half of the instructors were successful. However, the management of the rowdy engineering students prevented successful teaching and learning for between three and six instructors. Their classroom management problems are not particular to the instructional cycle approach, although the moving back and forth between plenary and individual work did aggravate such problems.

A major positive outcome of this experimental study was that content and pedagogy became major topics of both formal and informal faculty discussions. Instructors became much more conscious of their teaching, particularly of the subject matter problems and prerequisite skills of the students discovered during the seatwork or activity phase. These changes triggered sharing of ideas on general chemistry concepts and on teaching these concepts. Such discussions resulted in conducting special lectures for instructors on atomic structure, the geometry of electron orbitals and chemical bonding, and on visualization of atomic models using balloons and computers. The second author documented the following small group discussion that illustrates the value of sharing teaching ideas when a young instructor, $\mathrm{H}$, asked advice from his colleagues about how to introduce the atomic model.

An instructor with over 20 years experience in teaching General Chemistry answered confidently and told the group how she usually introduced atoms. Then another young instructor in his first year of teaching provided some alternative ideas and others started butting in. We ended up with quite a variety of ideas. The most experienced teacher then said: I have never known that there were so many ways to introduce the atomic model! (Journal, 15/9/00)

Both experienced and inexperienced instructors found alternative ways to introduce a topic and shared this. In the process of sharing experiences, all instructors learned.

In the first implementation by 13 instructors, improved student results were not yet expected as reforms usually go through several implementation cycles before they result in better 
learning. Furthermore, the coaching process and the small group discussions exposed quite a few instructor problems with the subject matter that will take several semesters to overcome. There were no baseline data on achievement because for many years there had been no departmental tests - a situation which in practice had resulted in instructors teaching different courses with the same syllabus. To address this situation, the first author and the $\mathrm{PhD}$ holders in the Department constructed a departmental test that resulted in an average test score of approximately 50\%. This low score was partly because most instructors had not yet completed about $25 \%$ of the material that was on the test. Nevertheless, these items had been included because the test was to serve as baseline data for future implementations. Student interviews indicated that the teaching approach enabled them to understand chemistry concepts better because of sharing ideas with peers and interaction with the instructor during the seatwork or activity phase. Students also realized that the broad aim of the approach was for them to take responsibility for their own learning. A second or third implementation of the approach is likely to show improvement of student achievement results. One instructor, G, who was already involved in the pilot study and had implemented the new course three times during the data collection phase of this study, had improved much in her teaching and was confident to teach a chemical engineering section with high academic ability students. Her improvement in terms of classroom management and student responsibility was spectacular. Both the first and second author observed her several times before the project and since. The third author observed her towards the end of the project and interviewed her enthusiastic class.

\section{Three case studies to illustrate how instructors implemented the course}

The instructors had varying degrees of success in implementing the new General Chemistry. Some instructors were successful, several were moderately successful, while a few instructors seemed to have low success in adopting the instructional cycle. This section presents three case studies of instructors selected from each category. The presentation of each case starts with a problem associated with the less successful instructors that was identified by the instructors and the students during interviews. The cases cited are with two successful instructors, F and G, and one partly successful instructor, $\mathrm{K}$, and are of particular value because they illustrate the difficulties that hinder the smooth implementation of the instructional cycle. 


\section{Case 1: Establishing an orderly classroom atmosphere}

A perennial problem in the implementation of the new course was the difficulty of most instructors to control inappropriate noise of students throughout the session. Although no serious student misbehaviours occurred, student noise was annoying and irritating not only to the instructors but also to the students themselves, as revealed during the interviews. This student noise was one of the causes of losing time during the class and much time was spent waiting for students to be quiet and reprimanding them.

Instructor F was successful in controlling the noise of the students. She managed the class by setting a good start in the semester, spending the first week of the semester organising the class. On the first day, she allowed students to become acquainted with one another in the class and reviewed the university policies regarding absences, tardiness and grading system. She set ground rules for the class such as students not being admitted if more than 15 minutes late, each student should provide and bring his/her own textbook and activity notebook to every class meeting, and should wear a nametag during class. Instructor $\mathrm{F}$ also informed students that the class would always start and end with a short prayer and assigned a student to lead the prayer each meeting. She emphasized that good behaviour during the lesson and active participation was expected of the students every meeting.

On the second day, Instructor F introduced the course and explained her policy on make-up tests and the teaching approach to be adapted in the course throughout the semester. She announced to the students that for each lesson a different teaching approach would be used that included a short lecture, an activity to work on, and a summary of each day's learning be given.

During the mini-lecture, I expect you to listen carefully, take notes when necessary and to raise a hand when you want to say something. Homework assignments will be checked regularly either by collecting them on paper, or by giving an unannounced quiz. Thus you need to work on your homework assignments seriously. Seatwork assignments will be provided, but most often questions or problem sets are taken from the textbook, therefore you are required to bring a textbook in class. The first few minutes of the seatwork 
activity is an individual task after which you will discuss your work with a seatmate and share ideas. No one is allowed to roam around the classroom to socialise during this phase. Everybody is expected to be on task. I'll be going around to check your activity notebook every now and then or you are free to consult me about your task. Consultation should be done one after another. In other words, no group consultation is allowed. After the seatwork, any student will be asked to report on their answers, discussion or to give a summary of what you had just learned. Do you have any questions?

(Observation 22/06/00)

On the third day and onwards, Instructor F began implementing the procedures she set, adding new procedures when needed. This excerpt of classroom practice shows that Instructor F set a good start in order to obtain cooperation from students. The general rules and procedures laid down by the instructor guided the students to successfully engage in all the learning activities. The instructor did not have to waste time restating these procedures every session. With this practice going on, eventually the students became accustomed to these routines and a good learning atmosphere was sustained.

In contrast, unsuccessful implementers of the instructional cycle had positive attitudes towards the new teaching scheme but they never required silence and therefore did not properly implement the instructional cycle and other features of the revised course.

Case 2: Managing student work in progress

Managing student work and learning was one of the difficulties identified by most instructors. These instructors came to recognize inadequacies in their skills related to meaningful interaction about the subject matter with individual students, the quality and appropriateness of questions asked during the seatwork, and knowledge of student learning difficulties. Instructor $\mathrm{G}$ proved to be successful to a certain extent having taught the new General Chemistry course for the third time. However, before the implementation, instructor $G$ had serious problems with classroom discipline. After coaching for one semester, she was able to manage her class efficiently and develop a process of continuous improvement. 
In a typical class taught by instructor $\mathrm{G}$, she started the session with spot-checking student homework which was to make an outline of the rules for naming ionic compounds. While moving around the class, she noted the exemplary homework of James, and requested the student to transfer his outline on to a transparency. The classroom discourse ran this way:

Instructor G: Well done class, everybody has done their homework. James will you please present the outline to the class.

James came forward, presented and explained his outline for naming ionic compounds using the overhead projector.

Instructor G: Are there any comments about the outline? Yes, Mario (who was raising his hand).

Mario: (Stood up saying) I think something is missing in the outline, the rule on metal ions with more than one oxidation number is not included.

Instructor G: Anyone who had same idea as Mario (pointing to Sheila, who volunteered to complete the outline). Very good, the outline is now complete. Let us use this outline to name and write the formulas of ionic compounds.

Open your book on page 158 numbers 5-9. Let us answer the first two numbers in the problem set. Then the other numbers will be your individual work. (Observation, 07/07/00)

After illustrating two examples to the class, the students worked individually. The instructor circulated around the classroom ensuring that everybody began the task, looked at students' papers, interacted with them for a few seconds, and continued moving around until everybody’s work was checked. Then she said:

Okay class, stop the individual work, face your seatmate and compare your answers. Find out any differences in your answers, discuss and come up with an agreed answer. Check your answers against the answers displayed on the instructor's table. You are not allowed to see the answers until you have done the seatwork assignment. (Observation, 07/07/00) 
The above description of her teaching practice shows three simple strategies employed by instructor $\mathrm{G}$ in attending to the student work. One strategy was the utilization of the homework assignment and student's previous knowledge as a link to the new lesson, which could enhance student's responsibility in the learning. The second strategy was to start the seatwork as a whole class activity before any individual work was given. This method resulted in the smooth transition from the plenary lecture mode to independent work. The third strategy was to circulate in the classroom as soon as the individual work has started and check on student progress periodically. This method allowed the instructor to give corrective feedback when needed and keep the students accountable for their own progress.

In contrast, unsuccessful implementers of the instructional cycle wasted a lot of time in the lesson by not having smooth transitions between seatwork and plenary and summary parts of the lessons and hence were less successful at managing student work in progress (See table 1).

\section{Case 3: Knowledge of students' learning difficulties}

An identified area of difficulty for instructors was the inability to identify students' learning difficulties and to use student ideas effectively as a basis for feedback and for the closure of the lesson. Instructor K, despite being a neophyte instructor, learned quickly how to identify student errors and provide immediate feedback as is illustrated in an excerpt of classroom discourse. After instructor $\mathrm{K}$ gave a mini-lecture on the Aufbau Principle and on the electron distribution in an atom, he gave the whole class seatwork activity.

Instructor K: Write the electron configuration of potassium.

Look at the periodic table and find the symbol and atomic number of potassium and begin the task individually.

Instructor K: (Moved around the classroom twice and looked at student papers. After five minutes he told the students to stop working). I saw two different electron configurations of $\mathrm{K}_{19}$ on your papers. (Then he wrote this on the chalkboard)

$$
\begin{aligned}
& 1 s^{2} 2 s^{2} 2 p^{6} 3 s^{2} 3 p^{6} 4 s^{1} \\
& 1 s^{2} 2 s^{2} 2 p^{6} 3 s^{2} 3 p^{6} 3 d^{1}
\end{aligned}
$$

Which of the two-electron configurations is true for the ground state of $\mathrm{K}_{19}$ ? (He called upon a student.) 
Anna Marie: The first one (referring to the electron configuration on the chalkboard).

Instructor K: Encircled the $1 s^{2} 2 s^{2} 2 p^{6} 3 s^{2} 3 p^{6} 4 s^{1}$ and then asked, What's wrong with the second electron configuration? Yes (pointing to another student).

Joseph: $\quad$ Electron should not go to 3d.

Instructor K: Why not? (Calling a student who was raising his hand.)

Jenny: $\quad 3 d$ has higher energy than $4 \mathrm{~s}$.

Myla: $\quad$ How do we know that 4s has lower energy than 3d?

Instructor K: Is there anyone who can answer that question? (There was a brief silence and no student hands were raised) Okay let us discuss the $\mathrm{n}+\mathrm{l}$ rule.

(Video Transcription, 6/07/00)

This is a typical case where an instructor realises the learning difficulties involved and has to resort to procedures. When a student raises the fundamental question "How do we know that 4s has a lower energy than 3d?”, instructor K recognized that at this point the answer cannot be explained in terms of deeper concepts and referred the students to a rule. Alternatively, the instructor could have given a phenomenological explanation and say that $\mathrm{K}_{19}$ is very similar to $\mathrm{Na}_{11}$ and therefore it was assumed that it has $4 \mathrm{~s}^{1}$ rather than $3 \mathrm{~d}^{1}$.

Instructor K, being the youngest and least experienced among the chemistry instructors, was strongly committed to learning the new approach of teaching. He tried to create a classroom atmosphere that encouraged the students to interact not only with instructor but also with each other. The interaction above shows how quickly the instructor was able to identify errors of students' work and to use this to start a discussion. Instructor K did not give corrective feedback outright, but instead introduced lead questions to encourage the students to participate and do the corrections themselves. Instructor K was able to lead a chain of argument discussion rather than use fill-in-the-blank choral responses.

In contrast, the less successful instructors looked or glanced at student papers while circulating in the classroom and failed to take note of students' errors and difficulties. Often these instructors spent more time helping students who requested assistance, resulting in them being unaware of the progress of other students. Similarly, errors and difficulties were to be 
the focus of feedback in the closure phase but the authors noted that instructors often resorted to providing answers to the seatwork assignment. Likewise, incorrect statements and misconceptions during discussion were ignored because the instructor was more concerned with procedural solutions to a problem than with conceptual understanding. This focus on formulas, procedures, and algorithmic solutions, not on concepts, is indeed a general and pervasive trend in Philippine science and mathematics classrooms (Berg et al., 1998; Ibe, 1993).

\section{Conclusions and Implications}

The quantitative and qualitative observation data showed that the integrated course and faculty development process was able to create visible changes in classroom teaching and learning. The use of the instructional cycle as the teaching scheme considerably contributed not only to the reduction of the time used for lectures and to an increase of time used for guided practice time, but it also helped to change the focus of nine instructors from teaching to learning. Some simple but essential basics improved. Student tardiness and absence were reduced. All students in 11 of the 14 classes had textbooks and brought them to class to be used during the seatwork or activity phase. Giving and checking homework and using a textbook every session became part of the teaching ritual until the students developed the habit of working independently on homework. These procedures eventually led to a majority of the students taking more responsibility for their own learning. The questioning behaviour of teachers improved markedly with a clear reduction of choral answers. The seatwork/activity phase provided an opportunity to be mentally active and realise that sharing of ideas during a small group discussion enhances learning, confidence and understanding of chemistry concepts taught.

It is important to note that instructors adapted the instructional cycle with varying degrees of success, classified as the successful, the transitory and the least successful group. Three instructors who were successful implemented the instructional cycle approach as intended with clear mini-lectures, well managed student seatwork activities and a closure or summary which included reactions to learning difficulties encountered during the seatwork phase. On average, $30 \%$ of the lesson time was spent for lecture, $50 \%$ for student seatwork activities and $20 \%$ for the closure or summary. This group of instructors had a well-managed classroom with rules and procedures about classroom routines set up at the beginning of the semester. It could be noted in the interviews as well as during the training, that these instructors had been 
very supportive of this change effort because they also believed that first year university students should be trained to be more independent with guided classroom tasks.

The partially successful group of six instructors was willing to learn and sometimes took risks while exploring the new teaching approach, holding the conviction that students should develop responsibility for their learning. However, the practiced shortened seatwork time provided in the class did not reinforce more opportunity for doing this. Inconsistency in implementing the routine procedures like checking homework led to students' confusion and misbehaviour. This group of instructors still experienced problems in how to condense a lecture into essentials, guide students to rely on a book and to identify student learning difficulties and errors. When caught in a difficult situation such as conflict of views during discussion or with students being off-task and misbehaving, these instructors tended to resort to the lecture mode instead of acting quickly to attend to the problem they had identified using other pedagogical skills.

The least successful instructors were cooperative in the desire to implement the instructional cycle approach but lacked the necessary skills of classroom management, handling student misbehaviour and decision-making. Furthermore, classroom problems were sometimes caused by confusion over content mastery and the inability of instructors to identify students' scientifically incorrect ideas and use these in their interactions.

The instructional cycle requires important skills, which many instructors had not acquired in their many years of lecturing. Learning these skills is not trivial and needs guidance from a coach in the classroom so that instructors are able to:

- condense essentials from the topic into a mini-lecture and properly distinguish main points from details;

- guide students in making effective use of the textbook;

- manage the class efficiently during transitions from one phase to another (e.g., plenary to individual or small group seatwork);

- listen to students during seatwork and small group discussion and identify students’ misconceptions and other learning difficulties;

- ask questions that stimulate ideas and call for higher order thinking skills;

- $\quad$ interact meaningfully about the subject matter with individual students; 
- assess students' work and use students' ideas effectively as a basis for feedback and for the closure of the lesson;

- monitor the work atmosphere in the class.

Furthermore, the increased emphasis on discipline, such as requiring students to be in class on time and to be prepared, to bring and use textbooks, initially required support of a coach.

The course and faculty development process described in this paper was only an initial step of many to follow. Once the basics have been addressed (students being present and on time, books brought to class, seatwork organized and running, students at work), the focus of development of teaching and learning will have to change to conceptual development and meaningful learning. This change will require a major effort from the instructors and students who have grown up in a system, which is heavily memory-oriented. The instructional cycle approach adopted in this study is an appropriate way to change incrementally from a lecture mode approach to active student learning. The mainly positive results thus far and the opportunity for teachers to learn from each other are encouraging.

We now return to the propositions of the model of Rogan and Grayson presented at the beginning of this article and comment on our Philippine experiences.

1. Zone of Feasible Innovation. For the majority of the instructors the implementation of the learning cycle was a major change in their teaching style but was within reach of the level of support provided. However, for a few instructors it was a bridge too far. The zone of feasible innovation and the clear and manageable steps are useful concepts.

2. Capacity to Support Innovation. In this project in a university chemistry department, the initial plans were based on professional development models derived from Fullan (1991) and Joyce and Showers (1988). During frequent informal meetings of coaches and departmental leaders next steps were formulated and subsequently tried out. Development of capacity ranged from converting lecture theaters into real classrooms tailoring existing incentive schemes, organizing logistics for chemistry demonstrations in class, ...to training the good implementers to become course developers themselves. 
Several instructors have since revised six other Chemistry courses according to the instructional cycle model and have acted as coaches in implementation.

3. Provision of Outside Support. A Dutch project provided support for a doctoral study and the extra depth and coaching it provided, a short-term consultant to commence the development for this course and other courses, and some modest funding for small expenses. The initial model of the consultant was changed considerably to fit into the Zone of Feasible Innovation and local conditions. The Dutch project allowed for unusual liberty in modifying next steps. Incentives for both the department and the instructors were fitted into the structure and typical rates of existing local schemes. Although funding was modest, the availability of outside support greatly enhanced the status of the project.

4. Opportunity to Reconceptualise the intended changes in their own terms and for their own context. This proposition was considered to be the most crucial component. Coaching and small group discussion helped instructors to reconceptualise the changes. Better yet if instructors can be given tasks to prepare part of the changes such as developing certain assignments, demonstration experiments, diagnostic tools, or assessment items. Ideally, the involvement of instructors in course development should be increased but it would require funding that is not available under local conditions.

5. Changing Teaching and Learning Practices. In this General Chemistry course development, the leaders and coaches were very conscious of the change in culture required. Indicators of a culture change were the shift of faculty room talk from social talk to discussion of chemistry and teaching and the evidence that lessons were being prepared whereas before many instructors just walked into the classroom and taught last year's lesson. 
6. Successful Implementation. In this project it was possible to ensure that the above propositions described by Rogan and Grayson were carefully aligned with local conditions so that essential changes took place during the project's implementation. However, to make such changes sustainable will still take years of sustained effort.

The propositions of the theory of curriculum implementation by Rogan and Grayson provided a useful framework to reflect on the innovation and its support structure. The theory could be a useful guide for the analysis of past and future curriculum implementation and faculty development projects.

\section{References}

Acedo, C. (2002). Teachers supply and demand in the Philippines. HDNED, The World Bank. Retrieved July 4, 2002, from the World Wide Web: www1.worldbank.org/education

Balce, M., Carale, L., Ferido, M., Guzman, F. de, Mendoza, A., Ogena, E., Savellano, J., \& Talisayon, V. (2000). Third International Mathematics and Science Study-Repeat: The Philippine Participation (Vol 1). Manila, Philippines: Science Education InstituteDepartment of Science and Technology.

Beeby, C.E. (1980). The thesis of stages fourteen years later. International Review of Education, 26(4), 451-474.

Bell, B., \& Gilbert, J. (1996). Teacher development: A model from science education. London: Falmer Press.

Berg, E van den., Alfafara, R., \& Dalman, T. (1998). Case studies of science and mathematics teaching in the Philippines and lessons for teacher and school development. Paper presented at the annual conference of the National Association of Research in Science Teaching, San Diego, USA.

Biggs, J. (1999). Teaching for quality learning at university. Buckingham: Open University Press.

Black, P., Wiliam, D. (1998). Assessment and classroom learning. Assessment in education: Principles, policies \& practice. 5(1), 7-74.

Brown, T.L., H.E. LeMay Jr., B.E. Bursten (2000). Chemistry the central science $\left(^{\text {th }}\right.$ edition). Prentice Hall, New Jersey (special international black and white edition).

Fullan, M.G., S. Stiegelbauer (1991). The new meaning of educational change ( $2^{\text {nd }}$ edition). London: Cassell Educational Ltd.

Fullan, M.G., (1993). Change forces: Probing the depths of educational reform. London: Falmer Press.

Gallos, M. (2003). Reconceptualizing a college chemistry course to improve teaching and learning. Unpublished doctoral thesis, Curtin University of Technology, Perth Australia.

Golla, E. F., \& de Guzman, E. S. (1998). Teacher preparation in science and mathematics education: A situational analysis. In E. B Ogena \& F. G. Brawner (Eds.), Science education in the Philippines: Challenges for development (Vol. 1, pp.41-106). Manila: National Science Education Congress. 
Hopkins, D. (2002). Educational innovation: generic lessons learned from (a) regional practice. In: A. Thijs, L. de Feiter, J. van den Akker (editors): International learning on education reform: towards more effective ways of cooperation. Amsterdam: Vrije Universiteit.

Ibe, M. D., \& Ogena, E. B. (1998). Science education in the Philippines: An overview. Paper presented at the National Science Education Congress, University of the Philippines.

Joyce, B., B. Showers (1988). Student achievement through faculty development. Longman.

Koballa, T. R. (1992). Peer coaching: capitalizing on constructive criticism. Science Teacher, 59 (6), $42-45$.

Kohler, F. W., Crilley, K. M., \& Shearer, D. (1997). Effects of peer coaching on teacher and student outcomes. Journal of Educational Research, 90(4), 240-249.

Locaylocay, J.R., Berg, E. van den, Magno, L. (2003). Changes in college students’ conceptions of chemical equilibrium, paper presented at the Biannual Conference of the European Science Education Research Association, Noordwijkerhout (Netherlands), 19 23 August, 2003.

Loucks-Horsley, S., Hewson, P., Love, N., \& Stiles, K. (1998). Designing professional development for teachers of science and mathematics. USA: Corwin Press, Inc.

Medley, D. (1977). Teacher competence and teacher effectiveness: A review of processproduct research. Washington D. C.: American Association of Colleges for Teacher Education.

Mortimer, C.E. (1986). Chemistry (6 $6^{\text {th }}$ edition). Wadsworth Publishing Company, Belmont (California). Special newsprint international edition.

Munro, P. \& Elliot, J. (1989). Instructional growth through peer teaching. In P. Wolfe \& P. Robbins (Eds.) Opening doors: An introduction to peer coaching. Alexandria: Association for Supervision and Curriculum Development.

Peterson, P. L. (1979). Direct instruction reconsidered. In P. L. Peterson \& H. J. Walberg (Eds.), Research on teaching: Concepts, findings and implications. USA: McCutchan Publishing Corporation.

Pugach, M. \& Johnson, L. J. (1995). Unlocking expertise among classroom teachers through structured dialogue: extending research on peer collaboration. Exceptional Children, 62, (2), 101-110.

Robbins, P. (1991). How to plan and implement a peer coaching program. Alexandria:Association for Supervision and Curriculum development.

Rogan, J.M., Grayson, D.J. (2003). Towards a theory of curriculum implementation with particular reference to science education in developing countries. International Journal of Science Education, 25(10), 1171-1204.

Rosenshine, B. \& Stevens, R. (1986). Teaching functions. In M. C. Wittrock (Ed.), Handbook of research on teaching, $3^{\text {rd }}$ edition. New York: Macmillan Publishing Company.

Rosenshine, B. (1983). Teaching functions in instructional programs. The Elementary School Journal, 83 (4), 335-351.

Somerset, A., Alfafara, R. \& Dalman, T. (1999). Effective and ineffective pedagogy compared: Science and mathematics teacher needs assessment study, Part II. Cebu City: University of San Carlos Science and Mathematics Education Institute.

Showers, B. (1985). Teachers coaching teachers. Educational Leadership, 42 (7), 43-48.

Showers, B. \& Joyce, B. (1996). The evolution of peer coaching. Educational Leadership, 53 (6), 42-45.

Vail, C. O., Tscantz, J. M., \& Beveil, A. (1997). Dyads and data in peer coaching. Teaching Exceptional Children, 30, (2), 11-12.

Walberg, H. J. (1991). Improving school science in advanced and developing countries. Review of Educational Research, 61 (1), 25-29. 
Wolfe, P. \& Robbins, P. (1989). Opening doors: An introduction to peer coaching. Alexandria: The Association for Supervision and Curriculum Development. 
Table 1: Time in minutes spent and percent for each phase in the instructional cycle.

\begin{tabular}{cccccccccc}
\hline Instructor & Actual & Plenary & $\%$ & Seatwork & $\%$ & Closure/ & $\%$ & Other & $\%$ \\
& time & lecture & & Activity & & summary & & & \\
& & & & & & & & & \\
\hline A & 62.7 & 38.9 & 62 & 17.7 & 28 & 5.6 & 9 & 0.5 & 1 \\
B & 75.0 & 25.0 & 33 & 34.2 & 46 & 13.6 & 18 & 2.2 & 3 \\
C & 55.3 & 22.3 & 40 & 17.4 & 32 & 8.9 & 16 & 6.7 & 12 \\
D & 52.0 & 30.4 & 58 & 10.2 & 20 & 4.4 & 8 & 7.0 & 14 \\
E & 40.0 & 31.1 & 78 & 4.0 & 10 & 3.0 & 7 & 1.9 & 5 \\
F & 68.5 & 19.5 & 28 & 35.4 & 52 & 12.4 & 18 & 1.2 & 2 \\
G & 79.7 & 25.3 & 32 & 52.2 & 66 & 1.1 & 1 & 1.1 & 1 \\
H & 30.0 & 11.7 & 39 & 6.6 & 22 & 7.7 & 26 & 4.0 & 13 \\
I & 86.0 & 33.6 & 39 & 37.3 & 43 & 14.2 & 17 & 0.9 & 1 \\
J & 63.3 & 25.4 & 40 & 26.8 & 42 & 10.6 & 17 & 0.5 & 1 \\
K & 43.0 & 19.0 & 44 & 11.0 & 26 & 8.0 & 18 & 5.0 & 12 \\
L & 70.5 & 9.0 & 13 & 30.5 & 43 & 27.5 & 39 & 3.5 & 5 \\
M & 39.0 & 21.6 & 55 & 10.1 & 26 & 6.1 & 16 & 1.2 & 3 \\
\hline
\end{tabular}

Note: Instructors A, B, F, G, I J and L taught a 1.5 hour lesson (twice per week) Instructors C,D, E, H, K and M taught a 1.0 hour lesson (three times per week) 
Table 2: Comparison of percentage of questions and the mode of answers during the pre-project stage and departmental stage

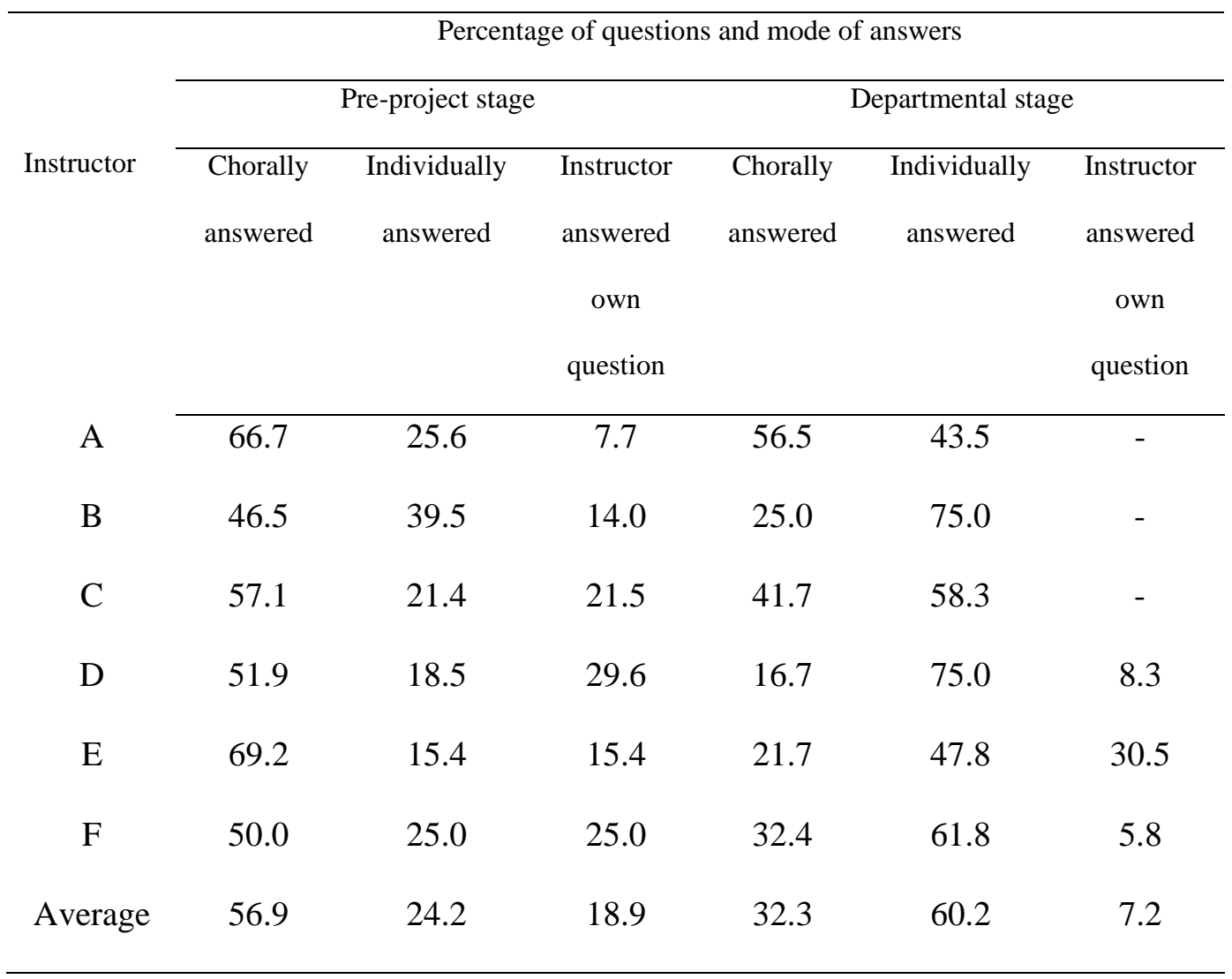


Table 3: Occurrence of selected implementation variables for 13 instructors in the seatwork activity phase

\begin{tabular}{|c|c|c|c|c|c|c|c|c|c|c|c|c|c|c|}
\hline \multirow[t]{2}{*}{ Variable description } & \multicolumn{13}{|c|}{ Instructors } & \multirow[t]{2}{*}{ Total } \\
\hline & $\mathrm{A}$ & $\mathrm{B}$ & $\mathrm{C}$ & $\mathrm{D}$ & $\mathrm{E}$ & $\mathrm{F}$ & $\mathrm{G}$ & $\mathrm{H}$ & $\mathrm{I}$ & $\mathrm{J}$ & $\mathrm{K}$ & $\mathrm{L}$ & $\mathrm{M}$ & \\
\hline Number of times conducted & 2 & 2 & 1 & 1 & 1 & 2 & 2 & 1 & 2 & 2 & 1 & 2 & 1 & \\
\hline \multicolumn{15}{|l|}{ Form of seatwork } \\
\hline individual & $\mathrm{x}$ & $\mathrm{x}$ & $\mathrm{x}$ & $\mathrm{x}$ & $\mathrm{x}$ & $\mathrm{x}$ & $\mathrm{x}$ & $\mathrm{x}$ & $\mathrm{x}$ & & $\mathrm{x}$ & $\mathrm{x}$ & $\mathrm{x}$ & 12 \\
\hline pair & & & & & & & & & & $\mathrm{x}$ & & & & 1 \\
\hline non graded & $\mathrm{x}$ & $\mathrm{x}$ & $\mathrm{x}$ & $\mathrm{x}$ & $\mathrm{x}$ & $\mathrm{x}$ & $\mathrm{x}$ & $\mathrm{x}$ & $\mathrm{x}$ & $\mathrm{x}$ & $\mathrm{x}$ & $\mathrm{x}$ & $\mathrm{x}$ & 13 \\
\hline \multicolumn{15}{|l|}{ Instructor's behaviours } \\
\hline $\begin{array}{l}\text { writes questions/problems on } \\
\text { the chalkboard }\end{array}$ & & $\mathrm{x}$ & & $\mathrm{x}$ & $\mathrm{x}$ & $\mathrm{x}$ & & $\mathrm{x}$ & & $\mathrm{x}$ & & $\mathrm{x}$ & & 7 \\
\hline $\begin{array}{l}\text { moves around so students start } \\
\text { immediately }\end{array}$ & & $\mathrm{x}$ & $\mathrm{x}$ & & $\mathrm{x}$ & $\mathrm{x}$ & $\mathrm{x}$ & & $\mathrm{x}$ & $\mathrm{x}$ & $\mathrm{x}$ & $\mathrm{x}$ & & 9 \\
\hline $\begin{array}{l}\text { moves around to ensure } \\
\text { everybody is at work }\end{array}$ & & $\mathrm{x}$ & $\mathrm{x}$ & & $\mathrm{x}$ & $\mathrm{x}$ & $\mathrm{x}$ & & $\mathrm{x}$ & $\mathrm{x}$ & $\mathrm{x}$ & $\mathrm{x}$ & & 9 \\
\hline Goes around and look at student's paper & $\mathrm{x}$ & $\mathrm{x}$ & $\mathrm{x}$ & $\mathrm{x}$ & $\mathrm{x}$ & $\mathrm{x}$ & $\mathrm{x}$ & $\mathrm{x}$ & $\mathrm{x}$ & $\mathrm{x}$ & $\mathrm{x}$ & $\mathrm{x}$ & $\mathrm{x}$ & 13 \\
\hline \multicolumn{15}{|l|}{ Interacts with students } \\
\hline individually & $\mathrm{x}$ & $\mathrm{x}$ & $\mathrm{x}$ & & & $\mathrm{x}$ & $\mathrm{x}$ & $\mathrm{x}$ & $\mathrm{x}$ & $\mathrm{x}$ & $\mathrm{x}$ & $\mathrm{x}$ & $\mathrm{x}$ & 11 \\
\hline in small group & & & & $\mathrm{x}$ & & $\mathrm{x}$ & & & & & & & & 2 \\
\hline as a whole class & & $\mathrm{x}$ & $\mathrm{x}$ & & $\mathrm{x}$ & & & & & $\mathrm{x}$ & $\mathrm{x}$ & $\mathrm{x}$ & & 6 \\
\hline Writes notes on the chalkboard & & & $\mathrm{x}$ & $\mathrm{x}$ & & & & & & & & $\mathrm{x}$ & $\mathrm{x}$ & 4 \\
\hline \multicolumn{15}{|l|}{ Students' behaviour } \\
\hline $\begin{array}{l}\text { answer the questions or } \\
\text { problems written on } \\
\text { chalkboard or transparency } \\
\text { read a topic from a textbook }\end{array}$ & & $\mathrm{x}$ & $\mathrm{x}$ & & & $\mathrm{x}$ & & $\mathrm{x}$ & $\mathrm{x}$ & & $\mathrm{x}$ & $\mathrm{x}$ & & 4 \\
\hline $\begin{array}{l}\text { answer textbook questions or } \\
\text { solve problems }\end{array}$ & $\mathrm{x}$ & & $\mathrm{x}$ & $\mathrm{x}$ & $\mathrm{x}$ & $\mathrm{x}$ & $\mathrm{x}$ & & $\mathrm{x}$ & $\mathrm{x}$ & $\mathrm{x}$ & $\mathrm{x}$ & $\mathrm{x}$ & 11 \\
\hline $\begin{array}{l}\text { discuss answer/ideas with } \\
\text { seatmate or group }\end{array}$ & & $\mathrm{x}$ & $\mathrm{x}$ & & & $\mathrm{x}$ & $\mathrm{x}$ & & $\mathrm{x}$ & & $\mathrm{x}$ & & & 6 \\
\hline $\begin{array}{l}\text { write answer or solution on the } \\
\text { board }\end{array}$ & $\mathrm{x}$ & $\mathrm{x}$ & & & & $\mathrm{x}$ & & & $\mathrm{x}$ & $\mathrm{x}$ & $\mathrm{x}$ & $\mathrm{x}$ & & 7 \\
\hline $\begin{array}{l}\text { Percent (estimate) of students who were } \\
\text { actively at work }\end{array}$ & & & & & & & & & & & & & & \\
\hline more than $70 \%$ & $\mathrm{x}$ & $\mathrm{x}$ & $\mathrm{x}$ & & & $\mathrm{x}$ & $\mathrm{x}$ & $\mathrm{x}$ & $\mathrm{x}$ & & $\mathrm{x}$ & $\mathrm{x}$ & & 9 \\
\hline $41-70 \%$ & & & & $\mathrm{x}$ & $\mathrm{x}$ & & & & & & & & $\mathrm{x}$ & 3 \\
\hline $10-40 \%$ & & & & & & & & & & $\mathrm{x}$ & & & & 1 \\
\hline less than $10 \%$ & & & & & & & & & & & & & & \\
\hline
\end{tabular}




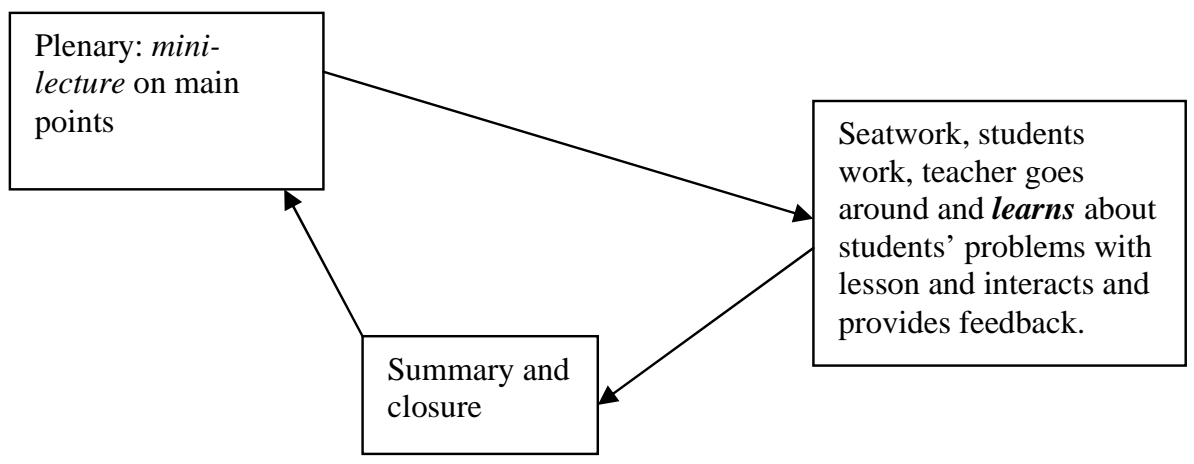

Figure 1: The Instructional Cycle 